type is, added Sir John, due, paradoxically, to one of the most beneficent events in the history of our civilization-the invention of the printed book, which brought with it the possibility of mass education. An inevitable result of the domination of education by the printed boek was the reduction to a position of relative unimportance of that training in observation, judgment and mental alertness which formed so important a part of education in the earlier phases of communal evolution. In the child's preschool life, we still have that kind of training, as also in later adult life of vocational employment. But in the intervening period of school life, the boy becomes in the main an absorber of information obtained from the printed page. The remedy lies not in further overloading the school curriculum, but in correcting some of the existing wastage. As to girls' education, Sïr John, believing it to be a question for the women of the country, declined to commit himself, except to say that the education of a girl should be permeated with the realization that the highest ideal of her sex is that of home and family.

\section{Higher Education in the Caribbean}

THE Commission on Higher Education in the Colonies (see Nature, August 21, 1943, p. 211) has appointed a committee of its members, and co-opted representatives from the West Indies, with the following terms of reference: "To review existing facilities for higher education in the British colonies in the Caribbean and to make recommendations regarding future university development for these colonies." The committee is constituted as follows : Sir James Irvine (chairman), vice-chancellor of the University of St. Andrews; Prof. A. M. Carr-Saunders, director of the London School of Economics and Political Science; Miss Margery Perham, reader in Colonial administration at the University of Oxford; Dr. R. E. Priestley, vice-chancellor of the University of Birmingham; Mr. P. Sherlock, secretary of the Institute of Jamaica ; and Mr. H. Springer, member of the House of Assembly, Barbados; with Mr. T. R. Rowell, assistant educational adviser at the Colonial Office (secretary). The committeo will spend some three months visiting Jamaica, Trinidad, Barbados and British Guiana. Mr. W. D. Inniss, lately assistant master at Queen's Royal College, Trinidad, will serve on the committee while it is in Trinidad, and Mr. J. A. Luckhoo, member of the Executive and Legislative Councils, British Guiana, while it is in that colony.

\section{An Idealist View of Special Publications}

IN a paper "Streamlining Production and Distribution of Current Periodical Articles" (Special Libraries, 34, No. 6, July-August 1943), Zeliaette Troy, librarian of the Boyce Thompson Institute for Plant Research, after directing attention to the difficulties which the present system of publication offers to individuals as well as to libraries, and to the drawbacks of interlibrary loans, film. copies and photostat copies, suggests a scheme for minimizing the mechanics of publication and distribution. Under this scheme, an author would complete his article and send it to the usual editors, by whom, on approval, it would be sent to a central printing office. There the manuscript and abstract would be stamped with the date of receipt, and the authorizing organization indicated. When the article and abstract are in printable form, they would receive a common chronological number, followed by a classification number, after which the cost accountant would put a price on the article and on the abstract in accordance with the number of copies to be printed, and both items would go to the printing establishment.

The printers would thus supply a stream of scientific articles uniform in size, with the author, title, name of the organization sponsoring and paying for it, the date of receipt, the master number and the classification number or numbers. They would also supply a periodical index and abstract journal issued both in its entirety and by subject sections. Members of a subscribing organization would receive one copy each of the publications authorized by it.' Individuals or libraries subscribing for all articles in certain classifications would be similarly supplied. The indexabstract journal would have an annual paid subscription charge both for the complete issue and its sections.

The advantages of the proposed system to the individual, in the absence of delays in publication and in being sure of seeing all articles on the subjects falling within the classifications for which he subscribes, in the relief from the burden of proof-reading and the distribution of proofs are clearly indicated, and the failure of the individual to distinguish between his working tools and his 'browsing' literature is emphasized : the latter might well be left to his library, and only those articles of fundamental and immediate importance to him taken into his private collection. Libraries would have the further advantages of being relieved of inter-library loans and expensive and inadequate reproductions. Binding problems would be simplified and some binding could be eliminated.

\section{Geological Society: Medal Awards}

The Council of the Geological Society announces the following awards: Wollaston Medal to Prof. V. M. Goldschmidt, professor of geology, Frederiks University and Museum, Oslo, for his outstanding contributions to Norwegian petrology, and his fundamental researches into the structure of crystals and the distribution of the chemical elements in the earth ; Murchison Medal to Prof. V. C. Illing, of the Imperial College of Science and Technology, for his talented contribution to oil geology and Palæozoic stratigraphy; Lyell Medal to Dr. N. R. Junner, of the Geological Survey of the Gold Coast and Sierra Leone, for his contributions to the stratigraphy of the PreCambrian and his discoveries of valuable minerals associated therewith; Wollaston Fund to Mr. A. G. Brighton, curator of the Sedgwick Museum, Cambridge, for his services to palæontology and his researches on the echinoderms; Murchison Fund to Mr. G. M. Stockley, of the Geological Survey, Tanganyika Territory, for his work on the stratigraphy, palæontology and mineral resources of East Africa; one moiety of the Lyell Fund to Dr. S. Buchan of the Geological Survey of Great Britain, for his work on underground water resources of the London area; another moiety of the Lyell Fund to Mr. E. W. J. Moore, of Haslingden, for his researches on carboniferous goniatites.

\section{Presidency of the American Chemical Society}

Prof. C. S. Marver, professor of organic chemistry in the University of Illinois, has been elected president of the American Chemical Society for 1945. Prof. Marvel will take office as president-elect on January 1, 
1944, when Dr. Thomas Midgley, jun., vice-president of Ethyl Corporation, and known for his discovery of tetraethyl lead, becomes president, succeeding Dr. Per K. Frolich, director of the Chemical Division, Esso Laboratories, Standard Oil Development Company, Elizabeth, New Jersey. Dr. Marvel was recently awarded the 1944 William $H$. Nichols Medal of the New York Section of the American Chemical Society. He has made outstanding contributions to research on the structure of vinyl polymers, used as synthetic plastics, particularly in the production of transparent aircraft parts, as rubber substitutes, and as thickening and blending agents in the chemical manufacturing industry. He has also made important researches on the structure of polymers of sulphur dioxide and olefines, and has developed practical methods for preparing amino-acids.

\section{Wind and Bird-Migration}

Dr. Norman H. Joy (Field, Dec. 11, 1943) has published a short account of observations on birdmigration maintained almost continuously for four years at Dungeness, on the coast of Kent. This is useful work, of a kind not often undertaken so intensively. $\mathrm{He}$ has, in particular, noted the conditions of departure across the English Channel in autumn. As only selected observations are given, it is difficult to make a critical assessment of the conclusion that birds of certain species, for example, swallows, leave only when there is a confrary wind. The frequency with which birds are seen migrating against the wind has often been remarked. To some extent the impression may be exaggerated-birds flying across the wind (as Dr. Joy points out) have to head partially into it to correct their drift; and birds flying against the wind, at reduced speed in relation to the ground, remain longer under notice. In any event, it is open to question whether the relation between wind and a migratory movement is one of cause and effect, or whether they have a common origin in the general meteorological situation. Dr. Joy's suggestion that birds find a head wind advantageous because it gives them more lift is untenable: once it is airborne, a bird can derive no lift from the body of air within which it moves (assuming, for simplicity, that the current is horizontal and of uniform strength), except as a result of its own air speed.

\section{Poisonous Reptiles of the World}

THE Smithsonian Institution "War Background Studies", No. 10 is on the poisonous reptiles of the world, by Doris M. Cochran (Smithsonian Inst., 1943). It contains brief accounts of all the principal poisonous reptiles arranged in geographical groups, namely, the United States, Latin America, Europe and northern Asia, India and Malaya, Africa and Australia, New Guinea and the South Pacific Islands. The brochure is illustrated with seventeen plates, the first of which is coloured and most of which contain two species. There is also a small selected bibliography and an appendix dealing with first aid treatment, the preparation of antivenin and directions to collectors. From it medical officers should be able to identify any of the ordinary poisonous reptiles with which they are likely to be concerned even without previous knowledge of the group. It is obvious also that it will be useful to others than to those for whom it is particularly written.

\section{Fishes from Philippine Seas}

HeNRY W. Fowler has described many new fishes in his recent paper "Contributions to the Biology of the Philippine Archipelago and Adjacent Regions. Descriptions and Figures of New Fishes obtained in the Philippine Seas and Adjacent Waters by the United States Bureau of Fisheries Steamer Albatross" (U.S. National Museum, Bull. 100, 14, part 2. Smithsonian Institution, 1943). These belong to several families and form an appendix to the detailed reports on these groups of Albatross fishes. There are ten new genera, one new sub-genus, one new sub-family and twenty-two new species in this paper. Many of these fishes are of striking form, notably Calliurichthys lineathorax n.sp., with its enormously long caudal fin as long as all the rest of the fish. All the illustrations are excellent.

\section{The Night Sky in February}

FuLl moon occurs on Feb. 9d. 05h. 29 m. U.T., and new moon on Feb. 24d. 01h. $59 \mathrm{~m}$. The following conjunctions with the moon take place: Feb. 3d. 06h., Mars $7^{\circ}$ N. ; Feb. 4d. 07h., Saturn $3^{\circ}$ N.; Feb. 9d. 1lh., Jupiter $0.4^{\circ}$ S.; Feb. 2ld. 20h., Venus $1^{\circ} \mathrm{S} . ;$ Feb. 22d. 20h., Mercury $1^{\circ} \mathrm{S}$. The following occultations of stars brighter than magnitude 6 take place: Feb. 4d. 22h. 58.6m., 57 Ori. $(D)$; Feb. 5d. 03h. 23.6m., 64 Ori. $(D)$; Feb. 7d. 18h. 36·7m., $d^{1}$ Canc. $(D)$; Feb. 7d. 23h. 43·0m., $\theta$ Canc. $(D)$; Feb. 17d. 06h. 01-Im., $\eta$ Lib. $(R)$. The times refer to Greenwich and $D$ and $R$ refer to disappearance and reappearance respectively. Mercury rises at $6 \mathrm{~h}$. $28 \mathrm{~m}$. at the beginning of the month and at $6 \mathrm{~h} .44 \mathrm{~m}$. at the end of the month, and is too close to the sun to be favourably seen. Venus rises a little before $6 \mathrm{~h}$. throughout the month and is a conspicuous object in the morning hours. Mars can be seen through a good portion of the night, setting at $3 \mathrm{~h}$. $57 \mathrm{~m}$., $3 \mathrm{~h}$. $26 \mathrm{~m}$., and $2 \mathrm{~h} .56 \mathrm{~m}$. at the beginning, middle and end of the month. Jupiter is in opposition on Feb. 11 and can be seen throughout the night, setting at $8 \mathrm{~h}$. $21 \mathrm{~m}$. and $6 \mathrm{~h} .20 \mathrm{~m}$. at the beginning and end of the month. Saturn is a little east of Mars and sets about 15 minutes later than Mars in the middle of the month. At the beginning and end of the month Saturn sets at $4 \mathrm{~h}$. $35 \mathrm{~m}$. and $2 \mathrm{~h} .42 \mathrm{~m}$. The planet is stationary on Feb. 20.

\section{Announcements}

WE regret to announce that Dr. W. W. C. Topley, F.R.S., secretary since 1941 of the Agricultural Research Council, and formerly professor of the division of bacteriology and immunology in the University of London, died on January 21, aged fifty-seven.

The Council of the Royal Aeronautical Society has elected Group Captain F. Whittle a fellow of the Society; such an election is a specialdistinction in recog. nition of work of great importance in aeronautics.

Mr. Atruee, Lord President of the Council, has announced that the Government has appointed the following committee to consider and make recommendations as to the development of television after the War : Lord Hankey (chairman); Sir Noel Ashbridge and Mr. Robert Foot, B.B.C.; Sir Raymond Birchall and Sir Stanley Angwin, General Post Office ; Mr. Harvey, Treasury ; Sir Edward Appleton, Department of Scientific and Industrial Research ; and Prof. J. D. Cockcroft, Ministry of Supply. 